\title{
UNDERSTANDING FREEDOM OF RELIGION IN A RELIGIOUS INDUSTRY: KOSHER SLAUGHTER (SHECHITA) AND ANIMAL WELFARE
}

\author{
Joel Silver
}

\begin{abstract}
The legality of ritual slaughter rests upon both law and merits. On the one hand, the international freedom of religion requires that communities can obtain meat of a suitable standard, and on the other, current scientific literature indicates that any distinct risks to animal welfare are manageable. Despite this, ritual slaughter remains controversial, particularly Jewish kosher slaughter (Shechita), for which electrical pre-stunning before throat-cutting-arguably the sine qua non of welfare risk management - is incompatible. Through a mixture of theological, legal, and scientific argument, this paper examines the level of protection Shechita receives as a manifestation of belief, with particular reference to developments in Australia and New Zealand
\end{abstract}

\section{INTRODUCTION}

We may have upset a relatively small religious minority, and I do appreciate their strong feelings for this issue but frankly I don't think any animal should suffer in the slaughter process. ${ }^{1}$

This comment was made shortly after unexpected changes to the New Zealand Animal Welfare (Commercial Slaughter) Code of Welfare 2010, ${ }^{2}$ including the introduction of mandatory electrical

* LLB (Hons) (Melb), GDLP (Leo Cussen Institute), Australian Lawyer and Officer of the Supreme Court of Victoria. This article was written as assessment for Advanced Legal Research in the undergraduate programme at Melbourne Law School. The author would like to thank his supervisor, Professor Carolyn Evans, who continued to provide assistance during her sabbatical as a Fulbright Scholar, and for whose patience he is grateful. He also wishes to thank Rabbi Meir Shlomo Kluwgant, whose insights into the practices and processes of Shechita were invaluable, and his father, Eric Silver, a victim of regular discussions with the author, at home and in the workplace, during the drafting process. Any errors are the author's own.

1 David Carter, Minister of Agriculture "Speech to Association of Rural Veterinary Practices" (James Cook Hotel, Wellington, 14 June 2010). 
pre-stunning for slaughter in response to animal welfare concerns. Through this policy, New Zealand indirectly banned slaughter in accordance with Jewish law, depriving the nation's small Jewish community of locally-sourced meat. This was compounded by strict bio-security restrictions on poultry imports, limiting kosher imports to costlier red meats. Whether the remark made by the Hon David Carter MP (the Minister) reflected some ulterior motive - that New Zealand would oppose ritual slaughter regardless of the merits - is a matter of personal opinion. But the decision clearly sat upon precarious foundations. The inference that Shechita causes suffering was an opinion, not a statement of scientific fact. The policy also raised issues under s 13 of the New Zealand Bill of Rights 1990, the "freedom of religion" provision. The outcome of a legal challenge we will never know; an agreement allowing for poultry slaughter was reached shortly before the hearing, and a separate agreement is expected for lamb. ${ }^{3}$ The Minister later admitted being unaware of the poultry restrictions and the New Zealand Herald obtained documents showing the Minister exceeded his authority by considering whether trade with Muslim nations would suffer were it known that only Shechita, not Halal slaughter (Dhabiha), was exempted from pre-stunning. ${ }^{4}$

The legality of so-called ritual slaughter (Shechita being the Jewish form) has long been controversial. ${ }^{5}$ Unfortunately, public discussion so far can only, at best, be described as confused. It is often discussed in conjunction with live animal exports, itself controversial in Australia following an ABC Four Corners investigation into Indonesian abattoirs. ${ }^{6}$ That many animal welfare groups dismiss ritual slaughter as redundant dogma is unhelpful; a campaign titled "Kosher Slaughter: Unjustifiable Pain and Torment - A Call to Ban Cruel Religious Killing" is one example. ${ }^{7}$ Hostility also comes from opponents of special treatment of religions more generally (for example, tax benefits or religious charitable trusts).

2 Animal Welfare (Commercial Slaughter) Code of Welfare 2010, issued by the Minister of Agriculture under the Animal Welfare Act 1999.

3 "New Zealand schechitah [sic] ban to go to court" Jewish Telegraphic Agency (Sydney, 18 November 2010); "Agreement allows NZ kosher slaughter of poultry" Jewish Telegraphic Agency (Sydney, 26 November 2010).

4 Auckland Hebrew Congregation Trust Board v Minister of Agriculture HC Wellington CIV-2010-485-1423, 25 November 2010; David Fisher "MP Carter makes quick u-turn" The New Zealand Herald (Auckland, 28 November 2010).

5 See "Comment The Jewish Shechita" (1892) 2 The British Medical Journal 1308; Catherine Pearce "Animal Slaughter in Melbourne: campaigns concerning the issue of Shechita, 1946-1958" (2007) 18 Australian Jewish Historical Society Journal 570.

6 Lorna Edwards "Ritual slaughter ruling condemned" The Age (Melbourne, 13 November 2009); see generally Tim Lindsey "Cattle exports to Asia are inevitably a live issue" The Australian (New South Wales, 9 June 2011).

7 SAFE: Religious Slaughter "Save Animals from Experiments" (2010) SAFE <www.safe.org.nz> 
I decided to write this paper in response to the literature review into ritual slaughter commissioned by the Australian Government in 2007, authored by David Adams and Allan Sheridan. ${ }^{8}$ The Primary Industries Ministerial Council (PIMC) had just released the review after deciding, until further consultation of stakeholders occurred, that existing arrangements for ritual slaughter would continue. ${ }^{9}$ Informed discussion of this topic is crucial, given the small scale of kosher production; ${ }^{10}$ whereas most would register a larger brand's absence from supermarket shelves, kosher is of significantly less relevance. My perspective benefits from intimate involvement in the relevant industries; I grew up in family enterprise responsible for significant levels of kosher and non-kosher meat processing in Victoria. That insight, into both kashrut and the Australian regulatory environment, has been invaluable in writing this paper. Though the New Zealand changes were unanticipated, they have provided a helpful case study.

This article considers what protection Shechita attracts under the international freedom of religion, as expressed by art 18 of the International Covenant on Civil and Political Rights ${ }^{11}$ (the ICCPR). I commence with an overview of the relevant Jewish law, focusing on the incompatibility of pre-stunning and Shechita, and the conditions of becoming a Jewish slaughterman (Shoichet). This is followed by a discussion of recent scientific literature, considering the different welfare risks for livestock and poultry from a risk management perspective. I suggest manageability of welfare risks, not subjective views on humaneness, is how the merits of ritual slaughter should be assessed. The kosher meat industry in Australia and New Zealand is profiled, alongside various regulatory mechanisms that allow ritual slaughter.

The discussion then shifts to the international freedom, outlining its requirements, and effect in Australia and New Zealand. Consideration is given to two relevant cases - Cha'are Shalom ve Tsedek $v$ France $^{12}$ (Cha'are Shalom) in the European Court of Human Rights (ECHR), and

8 David Adams and Allan Sheridan Specifying the Risks to Animal Welfare Associated with Livestock Slaughter Without Induced Insensibility (Department of Agriculture, Fisheries and Forestry, 2008).

9 The PIMC consists of representatives from the Australian federal and state governments, and the New Zealand Government; Tony Burke, Minister for Agriculture, Fisheries and Forestry, "Abattoirs' preparation of red meat discussed at Ministerial Council" (press release, DAFF09/350B, 7 November 2009); Lorna Edwards "No action on 'painful' slaughter" The Age (Melbourne, 6 October 2009); Naomi Levin "Status quo on ritual slaughter practices" The Australian Jewish News (Melbourne, 16 November 2009).

10 As an illustration, roughly 16,000 birds are slaughtered kosher each week, compared to seven million nonkosher (0.0023 per cent of the total number of birds slaughtered); see John Barnett, Greg Cronin and Peter Scott "Behavioural responses of poultry during kosher slaughter and their implications for the birds' welfare" (2007) 160 The Veterinary Record 45. I assume the 'two similarly sized' kosher plants both process 8,000 birds a week (16,000 in total) compared to the seven million of the overall poultry industry.

11 International Covenant on Civil and Political Rights (adopted by United Nations General Assembly 19 December 1966, entered into force 23 March 1976).

12 Cha'are Shalom ve Tsedek v France (27417/95) Grand Chamber, ECHR 27 June 2000. 
Schächten ${ }^{13}$ from the German Bundesverfassungsgericht (Federal Constitution Court). Unlike in New Zealand, these cases involved judicial review of decisions not to approve specific ritual slaughter applications under dispensation-based regulations. After some further policy considerations, I discuss why the international freedom embodies a communal right to participate in domestic Shechita. I also consider live exports, in particular, whether States must supply suitable meat to overseas religious groups. I end by recommending certain changes to increase transparency in ritual slaughter, which will enhance public debate and allay concerns.

This article seeks to enhance the quality of public discussions regarding religious methods of slaughter. Many relevant considerations are drowned out by the sheer emotive heat of the public debate. The particulars of Shechita must be considered in a broader socio-scientific context. All forms of slaughter involve welfare risks towards the animal, slaughter being an unpleasant process. This is, to borrow the phrase, the inconvenient truth of large-scale meat consumption. It is inappropriate to characterise certain forms of slaughter as humane, and others not, without reference to some objective criteria.

\section{JEWISH LAW (HALACHA) IN THE SECULAR STATE - THE ORIGINS AND EVOLUTION OF SHECHITA}

The issues surrounding Shechita cannot be understood without identifying the relevant Jewish law and practicalities of the Shoichet's trade (for example their training and qualification). To establish the latter, being absent from current studies, ${ }^{14}$ I interviewed Rabbi Meir Shlomo Kluwgant, currently Vice-President of the Organisation of Rabbis of Australia (ORA), immediate past President of the Rabbinical Council of Victoria (2004-2009), and a Shoichet of over 20 years standing; ${ }^{15}$ Rabbi Moshe Gutnick (Rabbinic Administer of the Kashrut Authority, and Senior VicePresident of the ORA) reviewed the interview transcript to affirm its accuracy. Kluwgant provides an insight not simply as a senior Australian rabbi, but one of the few individuals who actively teach and practice Shechita in Australia. That stated, Kluwgant made clear that the rules and practice of Shechita vary little across the world. For example, there is rabbinic consensus that pre-stunning is incompatible with principles expressed by the Torah and other authoritative commentaries. ${ }^{16}$

13 Schächten BVerfG, 15 January 2002, 1783/99, BvR (2002) [Schächten].

14 See Barnett, Cronin and Scott, above n 10 at 48.

15 Interview with Rabbi Meir Shlomo Kluwgant (the author, Melbourne, October 4 2010) transcript provided by Melbourne Law School (Melbourne) at [13]. Obtaining semicha (rabbinic ordination) is not a requirement. Rabbi Kluwgant was in fact a practicing Shoichet some years prior to obtaining semicha in 1992.

16 Ibid, at [25], [15] and [20]. 
The written Torah contains rules on animal consumption: permitted species; ${ }^{17}$ the prohibition on consuming blood; ${ }^{18}$ separation of milk and meat; ${ }^{19}$ and parts forbidden from consumption (mammals' sciatic nerve, and certain fats reserved for fire-offerings, both located in the hindquarter). ${ }^{20}$ There are also verses requiring kindness to animals: feeding one's animals before oneself; ${ }^{21}$ assisting your enemy's over-loaded donkey; ${ }^{22}$ and sending away a mother-bird before removing her eggs. ${ }^{23}$ Animals are sometimes given parity with man; for example, a master cannot cause his servants, his children, or animals to work on Sabbath. ${ }^{24}$ But the Torah remains silent on slaughter, save that it shall be "as I have commanded you". ${ }^{25}$ This alludes to the existence of the Oral Torah, those laws communicated by God to Moses at Sinai, but only transcribed by scholars in later times, first as the Mishnah and later the Gemmarah (collectively the Talmud). ${ }^{26}$ The laws of Shechita appeared in the former's section on Hullin (ordinary things), ${ }^{27}$ with significant discussion in later commentaries, notably Mishnah Torah ${ }^{28}$ and Shulchan Aruch. ${ }^{29}$

The Shechita handbook, Simlah Chadasha ${ }^{30}$ from which most Shochetim learn and consult, draws largely on the Yoreah De'ah section of Shulchan Aruch, ${ }^{31}$ as does a competing text, Beit David. ${ }^{32}$ Some Shochetim, including Kluwgant, familiarise themselves with both. ${ }^{33}$ As these texts

17 Deuteronomy 12:3, at 1010-1013. All paginated Biblical notes refer to the translations in Nosson Scherman and others (eds) The Chumash: The Stone Edition (5th ed, Mesorah Publications, New York, 1994).

18 Leviticus 7:26 at 578-579; Deuteronomy 12:15 at 1002-1003; 12:23 at 1004-1005.

19 Deuteronomy 12:21 at 1012-1013.

20 Genesis 32:33, at 176-177; Leviticus 7:24 at 578-579.

21 Deuteronomy 11:15 at 994-997; see also Natan Slifkin Man and Beast: our Relationships with Animals in Jewish Law and Thought (Yashar Books, Brooklyn, 2006) at 146.

22 Exodus 23:5 at 434-435.

23 Deuteronomy 22:6 at 1050-1051.

24 Exodus 20:10 at 410-411.

25 Deuteronomy 12:21 at 1004-1005.

26 See Commentary in The Chumash: The Stone Edition (5th ed, Menorah Publications, 1994) at [21].

27 Mishnah (Jewish Law), Order 5 (Sefer Kodashim), Tractate 3 ("Hullin").

28 Ibid.

29 Kluwgant, above n 15, at [4] and [6].

30 Ibid.

31 Ibid.

32 Ibid.

33 Ibid. 
are available only in Hebrew, I am prevented from direct engagement, beyond stating they are the textual source of Shechita practice. Central to Shechita is the Chalaf, a special knife of "exquisite sharpness", which is regularly checked and re-checked for imperfections during production. ${ }^{34}$ The Chalaf must achieve a clean incision of the structures at the front of the animal's neck (the trachea, oesophagus, carotid arteries and jugular veins). ${ }^{35}$ The incision involves five components:

(1) Shehiya: The incision must be uninterrupted, with a consistent level of force applied; ${ }^{36}$

(2) Derasa: The Chalaf must not be pressed against the neck through a "chopping motion", the correct procedure being a backwards-and-forward "cutting motion". ${ }^{37}$ That excludes using a guillotine (also problematic due to decapitation, which in severing the spinal cord reduces blood flow); ${ }^{38}$

(3) Halada: The Chalaf must be of adequate length, so as not to become coated in hide, wool or feathers;

(4) Hagrama: The incision must be applied upon the neck to allow the quickest and cleanest severance; and

(5) Ikkur: There must be no tearing of the tissues.

Additionally, the wound must be held open, to ensure exsanguination is uninhibited (all blood having to be removed). ${ }^{39}$ Shochetim in some communities also check the carcasses' lungs for adhesions to ensure they are completely smooth (glatt). Such meat is Glatt Kosher, though the term Not Glatt has been applied to meat produced with a lenient attitude to Jewish law generally. ${ }^{40}$

Though counterintuitive to outsiders, pre-stunning raises problems under two Biblical rules: neveila and treiffa. ${ }^{41}$ Neveila refers to kosher animals - as opposed to non-permitted animals - that

34 Ibid, at [23].

35 Stuart Rosen "Physiological Insights Into Shechita" (2004) 154 Veterinary Record 759.

36 Ibid.

37 Kluwgant, above n 15, at [23].

38 Ibid, at [21].

39 Rosen, above n 35, at 759.

40 Kluwgant, above n 15, at [17]-[18]; see generally. Cha'are Shalom Ve Tsedek v France, above n 12, at [32]-[34].

41 Both neveila (Deuteronomy 14:21) and treiffa (Exodus 22:30) have Biblical origins. It is forbidden for either to be eaten: see Moses Maimondes Mishneh Torah: Sefer Kedushah (Book of Holiness) at Halacha 8 (MaAchalot Assurot (Law of Forbidden Foods)); see also Yosef Karo Shulchan Aruch: Yoreah De'ah at ch 2. 
die other than by Shechita. ${ }^{42}$ Treiffa (torn) refers to live animals that are dying from some injury. ${ }^{43}$ If non-penetrative methods are used, a stunned animal does not become neveila per se, as no bones are broken, and they can make a full recovery. ${ }^{44}$ But if an animal is pre-stunned, then slaughtered, the cause of death becomes uncertain. An animal is neveila unless it is known, to a virtual certainty, that no factor other than Shechita initiated its death. ${ }^{45}$ By contrast, pre-stunning with a penetrative captive bolt (the ordinary method for cattle) shatters the skull, rendering the animal treiffa (in other words, the incision is performed upon an injured, dying animal). ${ }^{46}$ If this method is used, separate issues arise post-stunning. While the animal is not neveila or treiffa - the animal being uninjured, and guaranteed to die from Shechita - post-stunning hinders blood flow, as would severing the spinal cord or breaking the animal's neck. ${ }^{47}$ This leaves greater blood volume in the carcass, which renders the meat inadequate for those persons who apply the rules stringently. ${ }^{48}$ Australian regulations require that cattle are post-stunned (if not pre-stunned), and the local rabbinate(s) have deemed it acceptable; Kluwgant made clear, however, that no such leniency would be extended to pre-stunning. ${ }^{49}$

Only a trained slaughterman, or Shoichet, may perform Shechita. To become a Shoichet, states Kluwgant, students undergo a rigorous training programme, comprising theoretical and practical aspects, including a lengthy apprenticeship. ${ }^{50}$ The theoretical side entails studying the full 28 chapters of Simlah Chadasha, every rule considered with equal importance. ${ }^{51}$ This culminates in a written exam, with failure common from a single wrong answer; 52 many of Kluwgant's students choose to leave the programme at this stage. ${ }^{53}$ The practical side begins with the preparation and inspection of the Chalaf, a "pain-staking and very exacting science". ${ }^{54}$ As the smallest imperfection

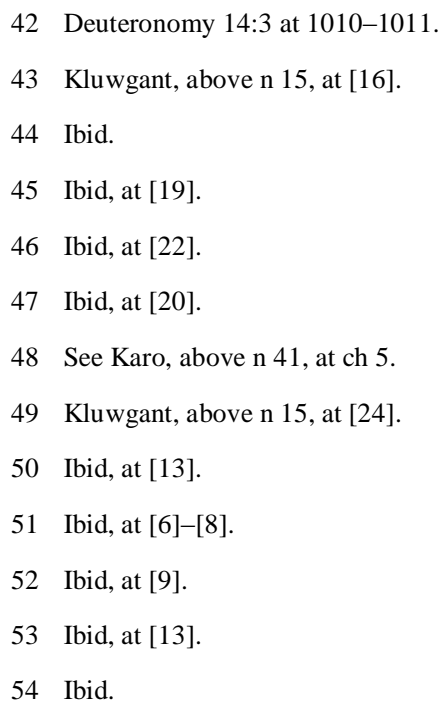


is unacceptable, this skill is perhaps the most crucial. ${ }^{55}$ Students must observe Shochetim in the abattoir before beginning their months of practice (first with poultry, then livestock). ${ }^{56}$ Once the Rosh HaShochetim (Head Shoichet) is confident in their abilities, he grants a testimonial (Hodaa). This is taken to an expert rabbi, who grants an acceptance (Kabbalah). ${ }^{57}$ This is a near-uniform process internationally, allowing Shochetim to move between communities. The local rabbinate only needs to establish bona fides, and to be satisfied from a practical demonstration of skills, which Kluwgant testifies makes the extent of their training clear. ${ }^{58}$ That stated, Shochetim can only practice while they maintain through knowledge of the rules. While no formal testing regime exists, there are various anecdotes in the texts where rabbinic authorities make unannounced visits to an abattoir, and dismiss Shochetim who cannot provide satisfactory answers to questions of theory and practice (for example, why Chalaf must be a particular length). ${ }^{59}$

It is also important to understand the tripartite employment relationships through which Shochetim are retained. While commissioned by kosher businesses, Shochetim are not actually employed by them. Rather, all Australian Shochetim are outsourced from communal kashrut authorities. For every body shecht-ed, the kashrut authority receives a fee to distribute as seen fit. While not a rule of Jewish law, this tripartite relationship ensures greater transparency and accountability, countering perceived conflicts-of-interest. Businesses exist to make money, and in a religious industry, that can be problematic. A Shoichet might purchase an animal, and shecht it perfectly. Consumers would nonetheless question his integrity: for example, if Shechita were faulty, would he simply absorb the loss of his investment in the animal, or would he still sell the (nonkosher) meat to his customers? The tripartite relationship means there is less temptation to cut corners, the Shoichet being independent of commercial considerations. ${ }^{60}$

\section{REVIEW OF THE SCIENCE: MANAGEABLE WELFARE RISKS}

When discussing scientific data, it is important to eliminate aesthetic considerations. How an observer perceives another's pain can differ from the actual experience, as Rosen illustrates: ${ }^{61}$

\footnotetext{
55 Ibid.

56 Ibid, at [11] and [12].

57 Ibid, at [11].

58 Ibid, at [13] and [15]

59 Ibid, at [14].

60 Ibid, at [28].

61 Rosen, above n 35, at 764.
} 
Characterisation of Shechita as 'cutting an animal's throat', with descriptions of blood spurting from the neck or of the late muscular spasms, are unattractive, to say the least. However, to the uninitiated, coronary artery bypass surgery is also visually unappealing!

Examples given of such "apparent pain" in human medicine are strokes (which are painless, despite the experience's severity) and many surgeons fail to notice, until after a procedure, that they have accidentally cut themselves. ${ }^{62}$

Much discussion on ritual slaughter discusses humaneness, with accusations that Shechita is inhumane. ${ }^{63}$ Such language, with respect, is unconstructive. True humane slaughter requires the complete elimination of pain and distress, which is unachievable. ${ }^{64}$ Defining humaneness in terms of risk management is more realistic: recognising slaughter's inherent unpleasantness, and the universal need for strategies to minimise suffering. This has been expressed as "avoidable pain and suffering". ${ }^{65}$ Unless the state outlaws all slaughter, its object is avoidance, not elimination, of pain and suffering.

The concept of welfare risks is not limited to throat cutting (sticking). Physical and psychological risks are present at every processing stage (for example farming, transportation and handling). Maintaining perspective requires that we segregate these risks to welfare (for example from restraints or lack of stunning) but keep the greater context in mind. ${ }^{66}$ The distinct risks of ritual slaughter only occur at the final stages, and like the many preceding risks, they too should be managed. These objective considerations must determine public policy, rather than narrow and capricious value judgements. What follows is a summary of the relevant vetinary literature on that final stage: sticking. Here, we see that there are distinctions between poultry and livestock beyond physiology; different slaughter methods are utilised and different regulations apply. ${ }^{67}$

62 Ibid, at 762 .

63 See RSPCA Australia "What is Kosher Slaughter?" (2010) <kb.rspca.org.au>; Edwards, above n 6; Peter Munro "Outrage grows on ritual killing" The Sunday Age (Melbourne, 26 June 2011) at 1.

64 David Adams and Allan Sheridan Specifying the Risks to Animal Welfare, above $\mathrm{n} 8$, at 6.

65 Council Directive 93/119/EC of 22 December 1993 (OJ L 340/21); see also David Adams and Allan Sheridan, above $\mathrm{n} 8$, at 1 .

66 Temple Grandin "Getting Religious with Slaughter" The Daf HaKashrus: A Monthly Newsletter for the Orthodox Union Field Representative (July-August 2010) at 51; see also Temple Grandin "Discussion of research that shows that Kosher or Halal Slaughter without stunning causes pain" (2010) Dr Temple Grandin's Website <www.grandin.com>.

67 Jeff Welty "Humane Slaughter Laws" (2007) 70 LCP 175 at 176 and 180; Australia has distinct standards for meat (AS 4696:2002) and poultry production (AS 4465:2001), incorporated into Victorian law by the Meat Industry Regulations 2005 (Vic), app 3. 
Let us begin with livestock. Adams and Sheridan, who suggested the risk management approach be applied to ritual slaughter in their comprehensive 2008 literature review, identified two welfare issues: ${ }^{68}$

(1) Responses to handling and restraint before sticking; and

(2) Sensations of physical pain after sticking, plus physiological responses to acute blood loss in conscious livestock.

The second issue concerns the two varieties of pain: phasic (from mechanical or thermal stimuli) and tonic (from injury or inflammation). ${ }^{69}$ Both cease following the irreversible blood loss that causes unconsciousness, tonic pain presenting the greater risk. ${ }^{70}$ What the literature showed, state the authors, is that tonic pain can be mitigated by pre-stunning (causing instant unconsciousness), or "competent throat cutting in some classes of animals" using ultra-sharp instruments (with a possible time lag to unconsciousness). ${ }^{71}$

For livestock, unconsciousness is induced by sticking - bilaterally severing the carotid arteries, which interrupts cerebral blood supply - and resulting exsanguination. The welfare risk arises from the possible "insensibility lag", ${ }^{72}$ which can be reduced by "insightful and capable" handling (among other precautions). ${ }^{73}$ However, the authors note that cattle face greater risks. In sheep, an "almost immediate" termination of cerebral bloody supply occurs - unconsciousness on average at 13-15 seconds - while it occurs eventually in cattle with developing circulatory collapse (their carotid arteries are "relatively too small" to sufficiently deplete blood volume). ${ }^{74}$ This difference is due to cattle's secondary cerebral blood supply (via the thoracic inlet), and also from their significantly greater brain-body disproportion. ${ }^{75}$ How these risks are dealt with was the subject of the 2009 Gibson et al study, which monitored noxious sensory input (or pain signals) in calves, using electroencephalogram recordings, to assess the effectiveness of pre- and post-stunning. ${ }^{76}$ The

68 Adams and Sheridan, above n 8, at [vi].

69 Ibid, at $[\mathrm{x}]$

70 Ibid, at [iv].

71 Ibid, at $[\mathrm{x}]$ and [xvii].

72 Ibid, at [xi]-[xii].

73 Ibid, at 61 .

74 Ibid, at 63.

75 Adams and Sheridan, above n 8, at 75; see also David Mellor, Troy Gibson and Craig Johnson "A reevaluation of the need to stun calves prior to slaughter by ventral-neck incision: An introductory review' stunning" (2009) 57(2) New Zealand Veterinary Journal 74 at 75.

76 As distinct from consciousness or sensibility; David Mellor, Troy Gibson and Craig Johnson, above n 75. 
methodology used, however, does differ from Shechita, including the knife being shorter, with no indication the sticking-wound was held open. ${ }^{77}$

Several findings were made. First, sticking provoked pain signals. ${ }^{78}$ Second, these pain signals resulted from the incision, rather than loss in blood pressure. ${ }^{79}$ The third and fourth findings concerned responses to pre- and post-stunning with a non-penetrative captive bolt. The vast majority of pre-stunned calves were insensible after three seconds, ${ }^{80}$ while those post-stunned at five seconds developed no response to the sticking. ${ }^{81}$ As concerns welfare risks, this means that, while sticking causes pain in cattle, both pre- and post-stunning effectively manage it.

An area where ritual slaughter has clear welfare benefits is in poultry slaughter. In their 2007 study, Barnett, Cronin and Scott took measurements on sensibility during production at one of Australia's two kosher-only poultry facilities. ${ }^{82}$ In contrast to ordinary slaughter, which is mechanised (birds shackled upside-down on an automated line), Shechita occurs by hand, with far lower throughput, and beneficial practices including individual handling, and sticking before shackling. ${ }^{83}$ The authors found birds became unconscious or insensible rapidly after sticking, at between $12-15$ seconds ( 26 seconds being the highest individual figure). ${ }^{84}$ The authors also examined the birds' physical response to sticking. Of 100 birds, 96 showed no physical reaction, the

77 Grandin, above n 66, at 53.

78 Troy Gibson and others "Electroencephalographic responses of halothane-anaesthetised calves to slaughter by ventral-neck incision without prior stunning" (2009) 57(2) New Zealand Veterinary Journal 77.

79 Troy Gibson and others "Components of electroencephalographic responses to slaughter in halothaneanaesthetised calves: Effects of cutting neck tissues compared with major blood vessels" (2009) 57(2) New Zealand Veterinary Journal 84.

80 Troy Gibson and others "Electroencephalographic responses to concussive non-penetrative captive-bolt stunning in halothane-anaesthetised calves" (2009) 57(2) New Zealand Veterinary Journal 90.

81 Troy Gibson and others "Amelioration of electroencephalographic responses to slaughter by non-penetrative captive-bolt stunning after ventral-neck incision in halothane-anaesthetised calves" (2009) 57(2) New Zealand Veterinary Journal 96.

82 Barnett, Cronin and Scott, above n 10; this study has been cited both in New Zealand (see the National Animal Welfare Advisory Committee Animal Welfare (Commercial Slaughter) Code of Welfare 2010 Report (2010)) and the United Kingdom (see the Farm Animal Welfare Council (United Kingdom) Report on the Welfare of Farmed Animals at Slaughter or Killing (Part 2: White Meat Animals) (2009) at [203]).

83 Barnett, Cronin and Scott, above n 10, at 48; see generally Farm Animal Welfare Council (United Kingdom), above n 82, at [201]-[202].

84 Ibid. 
remainder showing a "mild" response. ${ }^{85}$ This happened "well before" brain activity ceases with cessation of cerebral blood supply (up to 163 seconds). ${ }^{86}$

Overall, the distinct risks of Shechita are manageable. That is a relevant consideration to the international freedom, animal welfare being shown not to conflict with the Jewish or Islamic diets.

\section{THE AUSTRALIAN INDUSTRY AND COMPARATIVE LAW}

\section{A Kosher Meat in Australasia: The State of the Industry}

When preparing this article, I found that most commentary on ritual slaughter took an abstract approach. Legality seemed the only concern, little consideration being given to factors such as communal arrangements, for example, the bodies allowed to conduct Shechita. Can anyone simply arrange it? Is a central body necessary? Although these exclusions are not fatal (or necessarily relevant to freedom of religion), these are factors beyond science and Jewish law that decisionmakers should consider. Others include the parties involved, checks-and-balances employed by communities to ensure the meat's integrity, who becomes accountable to the state if abuses occur, and communal demographics. These considerations may vary, each community undertaking Shechita under different regulatory arrangements.

No discussion on Shechita is complete without an accurate picture of the kosher meat industry and the Jewish communities it serves. Of the 88,826 participants in the 2006 Australian Census who identified with Judaism, the majority came from New South Wales $(36,715)$ and Victoria $(41,105)$, with a sizeable number in Western Australia $(5,293) .{ }^{87}$ In New Zealand, 6,858 participants identified with Judaism in the 2006 Census. ${ }^{88}$ While these figures may be conservative - the Jewish Agency estimates there are 110,000 Jews in Oceania, including 103,000 in Australia ${ }^{89}$ - Jews, while not negligible, represent a relatively small demographic, and the regional kosher meat industry reflects that. ${ }^{90}$ Smaller Jewish communities throughout the Asia-Pacific (for example in Hong Kong or Thailand) are supplied from Australia. ${ }^{91}$ Of course, not all Jews would exclusively consume kosher meat, nor would all kosher consumers be Jews.

85 Ibid, at 47 .

86 Ibid, at $47-48$

87 Australian Bureau of Statistics "2006 Census of Population and Housing" (2010) <www.abs.gov.au>.

88 Statistics New Zealand "2006 Census of Population and Dwellings" (2010) <www.stats.govt.nz>.

89 Jewish Agency for Israel The Jewish People Policy Planning Institute Annual Assessment 2006 (Executive Report No 3): Major Shifts - Threats and Opportunities (Gefen Publishing House, Jerusalem, 2006).

90 This would not simply represent households, but related kosher industries such as caterers, hotels and restaurants.

91 Markets identified by Melissa Singer "Rabbis, meat watchdog stand by kosher practices" The Australian Jewish News (Melbourne, 7 August 2007). 
Australia's industry comprises several operations in Victoria and New South Wales, ${ }^{92}$ using a dozen regular Shochetim. ${ }^{93}$ Victoria has three kosher meat processors, ${ }^{94}$ each under different kashrut authorities (Mizrachi Organisation's Kosher Australia, Agudas Chabad, and Adass Israel). All have retail stores and distribute via supermarkets. Though a specialist facility is used for poultry, livestock are shecht-ed at commercial abattoirs with special permission to conduct slaughterwithout-stunning. New South Wales has a butcher and a retail poulterer, plus two supermarketspecific brands, one produced by New South Wales' kosher poultry facility, the other by an organic red meat producer. All are supervised by the New South Wales-based Kashrut Authority; ${ }^{95}$ Melbourne meat is also available in supermarkets. Additionally, a Melbourne-based operation (unconnected to local processors) employs Israeli Shochetim to shecht lamb for export to Israel. ${ }^{96}$ This is not sold locally, nor are local authorities involved in supervision. Previously, these facilities would have been supervised by a local Beth Din (rabbinic court); in the 20th century, specialist kashrut authorities emerged as Jews over greater geographic areas began to demand sect-specific, boutique supervision. ${ }^{97}$

The New Zealand industry, like its Jewish population, is far smaller. Shechita is performed by rabbinical staff from Auckland and Wellington Hebrew Congregations, and meat distributed by New Zealand synagogues. ${ }^{98}$ These arrangements have low annual throughput, comprising several thousand chickens and less than 100 cattle and sheep. ${ }^{99}$ By comparison, the kosher facility in Barnett, Cronin and Scott's study processed roughly 8,000 chickens weekly. ${ }^{100}$ Additionally, some Australian red meat is imported.

92 Jews outside Victoria and New South Wales can easily obtain products from these businesses.

93 Kluwgant, above n 15, at [34].

94 Confirmed by a Licence Search of the Primesafe Website (as at 28 August 2010) <www.primesafe.vic.gov.au>.

95 Kashrut Authority was formed in 1990 when Sydney's Beth Din and Yeshiva Rabbinate merged their kashrut arms, creating a monopoly over supervision. Both bodies continue to be involved in Kashrut Authority.

96 Greer Fay Cashman "Grapevine: Bibi's Balfour Bungle" The Jerusalem Post (11 April 2008) $<w w w . j p o s t . c o m>$.

97 Kluwgant, above n 15, at [31]-[32].

98 Stephen Levine The New Zealand Jewish Community (Lexington Books, Lanham, 1999) at 86.

99 Dan Goldberg "New Zealand Jews plan to fight for shechitah" Jewish Telegraphic Agency (New York, 27 June 2010) <www.jta.org>; see also National Animal Welfare Advisory Committee (New Zealand) Discussion Paper On The Animal Welfare Standards To Apply When Animals Are Commercially Slaughtered In Accordance With Religious Requirements (2001) at [7.1].

100 Barnett, Cronin and Scott, above n 10. 


\section{B Global Approaches to an Exemption}

Ritual slaughter has been exempted from general laws in varying ways, including dispensation, freestanding protection, and licence requirements. The Australian Meat and Poultry Standards, ${ }^{101}$ which articulate the hazard analysis critical control point (HACCP) approach to risk management used in Australia, ${ }^{102}$ suggests that authorities allow ritual slaughter under specific arrangements with facilities. ${ }^{103}$ Victoria, for example, grants facility licences subject to terms, which can include specific ritual slaughter procedures (for example quality assurance programmes, and poststunning).${ }^{104}$ New South Wales by contrast, allows slaughter "in accordance with the precepts of the Jewish religion" (though, like Victoria, cattle must be post-stunned); ${ }^{105}$ New Zealand has an analogous scheme. ${ }^{106}$ Export facilities can be granted an "instrument of exemption" from ordinary welfare rules in "exceptional" or "special commercial" circumstances. ${ }^{107}$

While "slaughter by a religious method" is exempt from pre-stunning in the United Kingdom, only slaughtermen with a secular and religious licence can perform it. ${ }^{108}$ Shechita licences in England and Wales are granted by the statutory Rabbinical Commission for the Licensing of Shochetim, ${ }^{109}$ comprising representatives from major British congregations. ${ }^{110}$ These regulations

101 Food Regulation Standing Committee Australian Standard for the Hygienic Production and Transportation of Meat and Meat Products for Human Consumption (AS 4696:2002, CSIRO, Collingwood, 2007) [AS 4696:2002]; Food Regulation Standing Committee Australian Standard for Construction of Premises and Hygienic Production of Poultry Meat for Human Consumption (AS 4465:2001, CSIRO, Collingwood, 2005) [AS 4465:2001].

102 PISC A Guide to the Implementation and Auditing of HACCP (CSIRO Publishing, Collingwood, 1997) Primary Industries Report Series 60; see in particular Export Control (Meat and Meat Products) Orders 2005 (Cth), s 6 (The Australian Meat Standard); Game, Poultry and Rabbit Meat Orders 1985 (Cth), s 7(b) (Compliance with Australian standards); Food Regulation 2010 (NSW), s 65(a)-(b) (Standards for meat processing plants); Meat Industry Regulations 2005 (Vic), s 22(2) (Issuing and renewal of licences).

103 See Food Regulation Standing Committee, above n 101, AS 4465:2001 at [15.26(b); Food Regulation Standing Committee, above n 101, AS 4696:2002 at [7.12].

104 Meat Industry Act 1993 (Vic), ss10, 14 and 38; for a critique of the Victorian arrangement see Malcolm Caulfield Handbook of Australian Animal Cruelty Law (Animals Australia, Melbourne, 2008) at [5.16].

105 Prevention of Cruelty to Animals Act 1979 (NSW), s 24 (Certain defences); Melissa Singer "Rabbis, meat watchdog stand by kosher practices" The Australian Jewish News (Melbourne, 7 August 2007); Kluwgant, above $\mathrm{n} 15$, at [35].

106 Animal Welfare Act 1999 (NZ), s 199 (Certain regulations to continue in force); see in particular National Animal Welfare Advisory Committee (New Zealand), above n 99, at [4.2].

107 Export Control (Meat and Meat Products) Orders 2005 (Cth), pt 2, div 4.

108 See The Welfare of Animals (Slaughter or Killing) Regulations 1995 (UK), sch 12 (Additional Provisions for Slaughter by a Religious Method); see also s 22 and pt I, s 2(a).

109 Ibid, at s 4(1)(c). 
also mandate certain abattoir procedures (for example handling and restraints). ${ }^{111}$ Having operated since 1933, the Rabbinical Commission attaches conditions to its licences, one being that Shochetim retain their licence subject to an annual Rabbinical Commission examination, in contrast to the perpetual secular licensing. ${ }^{12}$ Germany has a similar scheme; authorities are able, where necessary, to grant dispensation for groups whose 'mandatory rules require' ritual slaughter, and prohibit consumption of meats slaughtered in other methods. ${ }^{113}$

The French system is more complicated. While authorities may empower a religious organisation to licence slaughtermen, ${ }^{114}$ the only beneficiary has, in practice, been the Association Consistoriale Israélite de Paris (ACIP), incorporating the (orthodox Jewish) Chief Rabbinate of France. The ACIP has historically been the representative of French Jewry, other groups notwithstanding (for example the ultra-Orthodox, Progressive). ${ }^{115}$ The ACIP's Joint Rabbinical Ritual Slaughter Committee has been responsible for granting licences, with the Paris Beth Din (another ACIP organ) providing Shochetim to meat processors. ${ }^{116}$

\section{FREEDOM OF RELIGION: NECESSITY AND PROPORTIONALITY}

\section{A International Religious Freedom in Australasia}

Australia offers relatively weak protections for freedom of religion. ${ }^{117}$ But having ratified the ICCPR, ${ }^{118}$ Australia is, amongst other things, obliged to implement art 18, which provides: ${ }^{119}$

$110 \mathrm{Ibid}$, at sch 12 , pt IV.

111 Ibid, at sch 12, pt II and pt III.

$112 R v$ Rabbinical Commission for the Licensing of Shochetim, ex parte Cohen, CA, The Times, 22 December 1987 per Parker J; Rosen, above n 35, at 760.

113 Tierschutzgesetz, BGBI 1 1950, 24 July 1972 [Animal Welfare or Protection Act] (Germany), art 4a(2)(2).

114 Décret $n^{\circ} 80-791$ du 1 octobre 1980 [Decree No 80-221 of 1 October 1980] (France) JO, art 10.

115 Cha'are Shalom Ve Tsedek v France, above n 12, at [24]; see also Jon Bloomberg The Jewish World in the Modern Age (KTAV Publishing House, Jersey City, 2004) at 43-46; Loi du 9 décembre 1905 concernant la séparation des Églises et de l'État [law on the Separation of the Churches and State] (France) JO, 11 December 1905

116 Cha'are Shalom Ve Tsedek v France, above n 12, at [25].

117 Human Rights and Equal Opportunity Commission Article 18: Freedom of religion and belief (1998) at 25.

118 International Covenant on Civil and Political Rights, above n 11.

119 Ibid, at art 18 [emphasis added]. 
1. Everyone shall have the right to freedom of thought, conscience and religion. This right shall include freedom ... either individually or in community with others and in public or private to manifest his religion or belief in worship, observance, practice and teaching ... .

3. Freedom to manifest one's religion or beliefs may be subject only to such limitations as are prescribed by law and are necessary to protect public safety, order, health, or morals or the fundamental rights and freedoms of others.

Article 18 protects belief absolutely, while granting States limited power to restrict manifestations. ${ }^{120}$ It has been the template for numerous domestic instruments, including the New Zealand Bill of Rights Act 1990, ${ }^{121}$ the Human Rights Act 2004 (ACT), ${ }^{122}$ and the Charter of Human Rights and Responsibilities Act 2006 (Vic). ${ }^{123}$ It also shares parallel language with art 9 of the European Convention on Human Rights. ${ }^{124}$ Despite some textual variations, these instruments can bear similar interpretations and outcomes, ${ }^{125}$ including notions of necessity and proportionality. While Victoria and the Australian Capital Territories have guarantees resembling art 18, it has not been implemented by the Commonwealth Parliament. There is, however, High Court of Australia authority that, where the executive ratifies a treaty, individuals have a legitimate expectation that its terms will be followed, ${ }^{126}$ though doubt has since been expressed where the affected persons had no actual expectation that the terms would be followed. Australia has also ratified the First Optional

120 "Freedom of religion is not an absolute value" The Laws of Australia (1 June 2009) 21 Human Rights at [21.4.1080].

121 New Zealand Bill of Rights Act 1990, s15.

122 Human Rights Act 2004 (ACT), s 14.

123 Charter of Human Rights and Responsibilities Act 2006 (Vic), s 14; s 38 of the Charter requires that a public authority must give due consideration to Charter rights before making any decision.

124 The Convention for the Protection of Human Rights and Fundamental Freedoms (opened for signature 4 November 1950, entered into force 3 September 1953), art 9 [European Convention on Human Rights]; this observation was made in W Cole Durham Jr and Brett G Scharffs Law and Religion: National, International, and Comparative Perspectives (Aspen Publishers, New York, 2010) at 232-233; a minor difference is that the Convention says that limitations must be "necessary in a democratic society" (not simply "necessary").

125 United Nations Human Rights Committee General Comment No 22: The right to freedom of thought, conscience and religion (Art.18) UN Doc CCPR/C/21/Rev1/Add4 (1993) at [8] [General Comment No 22]; Malcolm Evans "Human Rights, Religious Liberty and the Universality Debate" in Andrew Lewis and Richard O'Dair (eds) Law and Religion: Current Legal Issues (Oxford University Press, Oxford, 2001) vol 4 205 .

126 Minister of State for Immigration and Ethnic Affairs $v$ Teoh (1994) 183 CLR 273 (HCA) at 291 per Mason and Deane JJ [Minister for Immigration v Teoh]; Re Minister for Immigration and Multicultural and Indigenous Affairs; ex parte Lam (2003) 214 CLR 1 (HCA) at 21 per McHugh and Gummow JJ and at 38 per Hayne J; see also "A legitimate expectation may be based on an undertaking given by the decisionmaker" The Laws of Australia (1 June 2010) 2 Administrative Law at [2.5.200]. 
Protocol to the ICCPR, which makes alleged rights violations reportable to the United Nations Human Rights Committee (UNHRC, which monitors implementation of the ICCPR) after all domestic remedies are exhausted. ${ }^{127}$ Treaty obligations are also influential at common law, ${ }^{128}$ with the High Court preferring to construe statutory ambiguities in favour of treaty obligations. ${ }^{129}$

In New Zealand, the executive, legislature and judiciary are bound by the New Zealand Bill of Rights Act, although courts may not invalidate legislation because of inconsistencies with the New Zealand Bill of Rights Act. ${ }^{130}$ Hence, the National Animal Welfare Advisory Committee's report on the Commercial Slaughter Code advised that the New Zealand Bill of Rights Act required an exemption for Shechita. ${ }^{131}$

\section{B Defining Protected Manifestations and Proportionality of Limitations}

Malcolm Evans suggests that, in evaluating the UNHRC's approach to art 18 and the international freedom, it is necessary to recognise three "pressure points":: 132

(1) What forms of belief enjoy the "freedom to manifest";

(2) What is a "manifestation"; and

(3) What is the scope of legitimate restrictions?

Article 18(1) outlines the freedom to manifest, granting protection to "worship, observance, practice and teaching", in either public or private, individually or in groups. That covers a broad range of activities, according to UNHRC's published interpretation of art 18 (General Comment No 22 ), which also notes that dietary regulations constitute both observance and practice. ${ }^{133}$ But the extent of protection is unclear: does it give negative protection, in other words to not eat contrary to those regulations (for example, exemption from "National Pork Day")? Or does it give a positive freedom, to implement those regulations without unreasonable impediment (for example Shechita)? As "religion" and "belief" are to be constructed broadly, ${ }^{134}$ the answer seems to be the latter. Article

127 First Optional Protocol to the International Covenant on Civil and Political Rights (opened for signature 19 December 1966, entered into force 25 December 1991), arts 1-2.

128 Mabo v Queensland (No 2) (1991) 175 CLR 1 at 42 (Brennan J).

129 See Chu Kheng Lim v Minister for Immigration (1992) 176 CLR 1 at 38 per Brennan, Deane and Dawson JJ; Minister for Immigration v Teoh, above n 126, at 287.

130 New Zealand Bill of Rights Act, ss 3-4.

131 National Animal Welfare Advisory Committee (New Zealand), above n 82, at 23.

132 Malcolm Evans "The United Nations and Freedom of Religion: The Work of the Human Rights Committee" in Rex J Ahdar (ed) Law and Religion (Ashgate, Aldershot, 2000) 35 at 37.

133 United Nations Human Rights Committee, above n 125, at [4].

134 Ibid, at [2]. 
9 of the European Convention on Human Rights uses a stricter approach, manifestations needing to be "intimately linked" with belief, such as acts of worship or devotion. ${ }^{135}$ This approach is described as a "necessity test": activities must be genuinely required by belief, not simply motivated or inspired by a belief. ${ }^{136}$ The ECHR has, unfortunately, been inconsistent in applying the test, leaving its content unclear. ${ }^{137}$ Cha'are Shalom, for example, made no reference to previous judgements, the majority referring only to the textual basis of kashrut, which they held "necessitates special slaughter processes". ${ }^{138}$ The relevance of previous legislative recognition was also not specified. ${ }^{139}$ I would suggest that, if a group activity has previously warranted protection, its significance does not change along with government policy.

Article 18(3) deals with Evans' third pressure point, the proper scope of restrictions (in other words, what makes restrictions valid), ${ }^{140}$ providing that limitations must:

(1) be prescribed by law;

(2) have the objective of furthering public safety, order, health, morals, or the fundamental rights and freedoms of others; and

(3) be necessary to further that objective, being motivated by, directly related, and proportionate to, that specific need.

A limitation must be directly related, and only related, to an objective in the second criterion, which exhausts the grounds for limitation. ${ }^{141} \mathrm{I}$ have expressed the third criterion with reference to General Comment No 22, and also to Durham and Scharffs' commentary on the European Convention on Human Rights. ${ }^{142}$ Both approaches display similar notions, confirming Evans'

135 A v United Kingdom (1984) 6 EHRR 558; see also $R$ (Williamson) v Secretary of State for Education and Employment [2005] UKHL 15, [2005] 2 AC 246 at [32] per Nicholls LJ, discussed in Mark Hill "Interpreting the European Convention on Human Rights in the United Kingdom Courts: The Impact for Religious Organisations" (Paper presented at the European Consortium for Church and State Research, Cyprus, November 2007) at 7.

136 Carolyn Evans Freedom of Religion Under the European Convention on Human Rights (Oxford University Press, Oxford, 2001) at [6.5.1] and [6.6.1]; see also Arrowsmith v the United Kingdom (1981) 3 EHRR 218 at [71]; $R$ (Williamson) $v$ Secretary of State for Education and Employment, above $\mathrm{n} 135$; see generally $R$ (Begum) v Denbigh High School Governors [2006] UKHL 15, [2007] 1 AC 100.

137 Evans, above n 132, at [6.5.1].

138 Cha'are Shalom Ve Tsedek v France, above n 12, at [18].

139 Ibid, at [5].

140 The equivalent paragraph is the European Convention on Human Rights, above n 124, art 9(2).

141 United Nations Human Rights Committee, above n 125, at [3]-[4] and [8].

142 See ibid, at [8]; Durham and Scharffs, above n 124, at 232-233. 
observation that, while no universally accepted formulation of religious freedom exists, there is an "accepted international approach" (Evans' italics). ${ }^{143}$ Assuming the formal requirements are satisfied, the limitation must not only be necessary, but proportionate, to fulfil that objective. For art 9, limitations must respond to a "pressing social need". ${ }^{44}$

The necessity and/or proportionality of limitations will be determined on the individual case, though courts tend to find otherwise if States might adopt a less restrictive measure, legitimate objectives alone being insufficient. ${ }^{145}$ To illustrate, South Africa's Constitutional Court invalidated a blanket ban for possession of "dependence-producing substances", insofar as it criminalised Rastafari customs involving cannabis, ${ }^{146}$ despite the public health purpose of avoiding harmful use. ${ }^{147}$ The Court, after noting that cannabis could be used safely, ${ }^{148}$ indicated that, if medical exemption was viable, so too was a religious one (albeit with risks). ${ }^{149}$

Which objectives could support the limitations upon ritual slaughter? While the majority in Cha'are Shalom found the ACIP's effective licensing monopoly was not a limitation, if it were, they found it allowable on several bases. First, slaughterhouse regulations generally further public order and health. ${ }^{150}$ Secondly, Shechita is required to be performed in slaughterhouses by licensed Shochetim. ${ }^{151}$ Additionally, the objectives were reinforced by minimising the number of approved bodies (despite the applicant's capacity to follow the regulations not being disputed). ${ }^{152}$ The German case Schächten considered another angle. As a regulatory objective, animal welfare draws upon "the feelings of broad sections of the population". ${ }^{153}$ But reliance on public sentiment and morality can be problematic, as it is not necessarily well-reasoned understanding, and because doing so can impose a level of moral superiority over minority traditions. ${ }^{154}$ Indeed, the UNHRC has observed

143 Evans, above n 125, at 209.

144 Durham and Scharffs, above n 124, at 205.

145 Ibid, at 233.

146 Prince v President of the Law Society of the Cape of Good Hope (CCT36/00) [2002] ZACC, 2002 (2) SA 794 at [85].

147 Similar to "protection of public health"; ibid, at [26] and [53].

148 Ibid, at [60]-[61].

149 Ibid, at [69] and [73].

150 Cha'are Shalom Ve Tsedek v France, above n 12, at [68].

151 Ibid.

152 Ibid, at [23]-[24] and at [29].

153 Schächten, above n 13, at [32]; see also Sebastian Poulter Ethnicity, Law and Human Rights: The English Experience (Clarendon Press, Oxford, 1998) at 144.

154 Ibid, at 146. 
that, if used to limit manifestations, morality should not rely on a single tradition, but incorporate the values held by minorities alongside those of larger and more influential groups. ${ }^{155}$

What about fundamental rights and freedoms? Does this objective also apply to animals in the ritual slaughter context? Poulter suggests this is conceivable, but that it would entail recognising that animals possess all "fundamental rights" under the Covenant. ${ }^{156}$ The right to life, for example, raises doubts about farming, hunting, and slaughter. A significant problem is that animals are not capable of enforcing these rights. ${ }^{157}$ It would also be inconsistent with the common law conception of animals (discussed later in part VI). Alternatively, Poulter suggests this objective could support labelling of ritually slaughtered meat, so that consumers can choose whether they eat it, as the European Union is considering. ${ }^{158}$

A legitimate aim alone, however, is insufficient to limit Shechita. Any limitation must be proportionate, as discussed in Cha'are Shalom, and two views emerged on that point in that case. The majority took a narrow position - what I would term an "availability approach" - requiring only the availability of acceptable meat, whether or not produced locally, or produced by a certain group. The minority approach was thoroughly reasoned, requiring "domestic facilitation" of ritual slaughter. That a state authorises one Jewish group to conduct Shechita does not justify declining applications from other Jewish groups. ${ }^{159}$ Schächten saw similar conclusions reached, but with greater emphasis on the communal and consumer-retailer relationships. ${ }^{160}$

\section{Proportionality in Ritual Slaughter and Shechita}

\section{The Narrow Approach - Availability of Acceptable Meat}

As discussed, the ACIP controls Shechita-licensing in France. ${ }^{161}$ This saw the Interior Minister and Deux-Sèvres prefect, in February 1987, refusing to grant further licences to the applicant. ${ }^{162}$ Both decisions were upheld on appeal. ${ }^{163}$ The applicant argued before the ECHR that this infringed

155 United Nations Human Rights Committee, above n 125, at [8].

156 Poulter, above n 153, at 143.

157 Ibid.

158 Robyn Rosen "EU labels threat to kosher prices" The Jewish Chronicle (London, 7 September 2010).

159 Cha'are Shalom Ve Tsedek v France, above n 12, at [1].

160 Schächten, above n 13, at [40].

161 Cha'are Shalom Ve Tsedek v France, above n 12, at [25].

162 Ibid, at [40]-[44].

163 Ibid. 
their communal right to manifest under art 9. ${ }^{164}$ And indeed, the majority acknowledged the applicant's members did not accept the ACIP's standards (largely concerning Glatt inspections). ${ }^{165}$

The majority found that mechanisms in the slaughterhouse regulations sought to safeguard religious freedom, and that regulating Shechita in itself did not interfere with the freedom of religion. ${ }^{166}$ An interference, they reasoned, would only arise where: ${ }^{167}$

[T]he illegality of performing ritual slaughter made it impossible for ultra-orthodox Jews to eat meat from animals slaughtered in accordance with [relevant] religious prescriptions...

But the majority found no such "impossibility", even though the applicant had been persistently and continually arranging unlicensed (and illegal) Shechita. ${ }^{168}$ This was on three distinct grounds: ${ }^{169}$

(1) Satisfactory Glatt kosher meat could be 'easily' obtained from Belgium;

(2) Several ACIP-supervised butcher shops produced Glatt meat; and

(3) The applicant could arrange to conduct Shechita under the ACIP's auspices (this had not occurred due to financial disagreements, the ACIP wishing to charge a slaughter tax double that of the applicant).

Because of this availability - the applicant's members were not "in practice" unable to obtain acceptable meat - art 9 did not require recognising the "right to take part in person in the performance of ritual slaughter and the subsequent certification process". ${ }^{170} \mathrm{Had}$ an interference been found, the majority found limiting permission to conduct Shechita would be proportionate, furthering public order (state monitoring slaughter) and the protection of health (guaranteeing minimum hygiene in slaughterhouses). ${ }^{171}$

\section{The Broad Approach - Domestic Facilitation}

The minority in Cha'are Shalom disagreed with the narrow approach. In their view, the state must give "careful consideration" to all licence applications, even where applicants profess the same

\footnotetext{
164 Ibid, at [58].

165 Ibid, at [66].

166 Ibid, at [77].

167 Ibid, at majority judgment [80].

168 Ibid, at [80]-[81].

169 Ibid, at majority judgment [81].

170 Ibid, at majority judgment [82] [emphasis added].

$171 \mathrm{Ibid}$, at [68] and [84].
} 
faith as an approved body. ${ }^{172}$ They felt it was "particularly inappropriate" to suggest that the applicant negotiate with the ACIP (to perform slaughter under its auspices); as the ACIP represented a majority of French Jewry, it was "least well-placed to assess the validity of minority claims". ${ }^{173}$ Additionally, while tensions will arise in divided communities, they noted that this was an avoidable consequence of pluralism, the State's role being to facilitate tolerance between the competing groups, rather than uniformity. ${ }^{174}$ Their Honours also dismissed the alternatives to communal Shechita as irrelevant. ${ }^{175}$ Subsequent commentary has focused on the import option, whose viability relies on the legality of Shechita in other States. If, as a matter of precedent, foreign courts endorse this solution, the argument becomes an incoherent fallacy. ${ }^{176}$ States effectively outsource their treaty obligations, failing to comply on the basis that other States will.

The minority also highlighted the relationship between art 9 of the ICCPR and art 14 of the European Convention on Human Rights, the latter providing that rights "shall be secured without discrimination on any grounds, such as ... religion". ${ }^{177}$ Discrimination, they wrote, arises if: ${ }^{178}$

States treat persons or groups in analogous situations differently without providing an objective and reasonable justification ... a difference of treatment is discriminatory ... if it does not pursue a "legitimate aim" or if there is not a "reasonable relationship of proportionality between the means employed and the aim sought to be realised".

The minority found no justifications for the difference of treatment, such as public health (the applicant not unable to comply with slaughterhouse regulations). ${ }^{179}$ Finally, their Honours held that, while France might, in some contexts, legitimately wish to deal only with the "most representative" community organisations, that was irrelevant here. ${ }^{180}$ A second source of kosher meat presented no threat to public order within the Jewish community, as would the applicant (representing 40,000) challenging the ACIP's status as official representative of French Jewry (representing 700,000). ${ }^{181}$

172 Ibid, at minority judgment [1].

173 Ibid.

174 Ibid.

175 Ibid, at 24 .

176 Claudia Haupt "Free Exercise of Religion and Animal Protection: A Comparative Perspective on Ritual Slaughter" (2007) 39 Geo Wash Intl L Rev 839 at 855.

177 European Convention on Human Rights, above n 124, art 14; see also International Covenant on Civil and Political Rights, above n 11, art 2.

178 Cha'are Shalom Ve Tsedek v France, above n 12, at minority judgment [2].

179 Ibid, at 29.

180 Ibid.

181 Ibid. 
The minority also noted that, for French Muslims, ritual slaughter licenses had been granted "fairly liberally", without undermining public order or health. ${ }^{182}$ This contrasted with the German case of Schächten (a Sunni Muslim butcher operating in the Hesse state), the complainant arguing that, as Jewish butchers were granted permission to perform ritual slaughter, Islamic butchers were, by analogy, entitled to permission. ${ }^{183}$ Schächten, however, arose under quite different circumstances.

Until September 1995, the complainant, a practicing Sunni Islamic Turkish citizen, ran a butcher shop, having been granted permission to slaughter without pre-stunning. ${ }^{184}$ A Federal Administrative Court ruling, however, found that denying permission for slaughter-without-stunning did not interfere with religious freedom (as guaranteed under the Basic Law). ${ }^{185}$ The Bundesverfassungsgericht said: ${ }^{186}$

[Adherents are not] forced to eat the meat of animals that were not ritually slaughtered... [It] does not ban the consumption of the meat of animals that were ritually slaughtered. The adherents... can change over to food of vegetable origin or to fish, and they can resort to meat that is imported... Certainly, meat is a usual food today. Doing without meat, however, does not constitute an unreasonable restriction of the freedom to develop one's personality.

In the same decision, the Bundesverfassungsgericht found there was no "mandatory provision" in Islam against consuming pre-stunned animals. ${ }^{187}$ A counter to this finding came from the Muslims' Central Council, who submitted to the Bundesverfassungsgericht that an opinion from $\mathrm{Al}$ Azhar University in Cairo (which stated Muslims could consume non-ritually slaughtered meat in emergencies) was misinterpreted. ${ }^{188}$

The authorities refused to renew the complainant's permission on this basis. Before the Bundesverfassungsgericht, the complainant argued, first, that the lower court wrongly determined the Islamic position on ritual slaughter, second, that no court can decide whether a religion prohibits pre-stunning, third, that the decision denied the complainant's right to occupational freedom (in

182 Ibid.

183 Schächten, above n 13, at [23]

184 Ibid, at [14].

185 Grundgesetz für die Bundesrepublik Deutschland [Basic Law of the Federal Republic of Germany], art 4.

186 Schächten, above n 13, at [11] [translated to English from German].

187 Ibid, at [12].

188 Ibid, at [25]; the contention surrounding this opinion is discussed in Pablo Lerner and Alfredo Mordechai Rabello "The Prohibition of Ritual Slaughtering (Kosher Shechita and Halal) and Freedom of Religion of Minorities" (2006) 22 JL and Relig 1 at 4. 
other words to practice as a distinctly "Muslim butcher"), and fourth, that the decision constituted unequal treatment of Islamic and Jewish butchers. ${ }^{189}$

The Bundesverfassungsgericht upheld the appeal unanimously, finding that, while the relevant regulatory mechanisms were valid, the impugned decisions were not. ${ }^{190}$ It accepted that ritual slaughter, beyond the mere preparation of acceptable meat for the butcher and his customers, was "an expression of a basic religious attitude ... for the complainant as a pious Sunnitic Muslim". ${ }^{191}$ Even if it was not, the Bundesverfassungsgericht indicated that, given the complainant personally believed pre-stunning was incompatible with Islam, a decision-maker must give due consideration to those individual views, to ensure respect for his occupational freedom. ${ }^{192}$

The Bundesverfassungsgericht then proceeded to address the practical importance of domestic slaughter. They reasoned that, if butchers merely supplied imported meat, product integrity would be uncertain as, first, the butcher himself is not involved in production, he cannot be certain of product integrity, ${ }^{193}$ and second, his customers have no personal contact with the actual processor, meaning "the confidence that goes with that contact" dissipates, imported meat being "fraught with the insecurity [as to] whether the meat really complies with the commandments of Islam". ${ }^{194}$ The Bundesverfassungsgericht also noted that as "meat is a common food" in Germany, requiring Muslims to involuntarily forgo meat could "hardly be regarded as reasonable". 195 Those considerations must be weighed by the state (alongside other provisions in the Tierschutzgesetz). ${ }^{196}$ An exemption cannot be refused where it would facilitate the observance of religious dietary laws. ${ }^{197}$ The state cannot make any values judgements regarding the humanity of such slaughter where it has that religious purpose. ${ }^{198}$

189 Schächten, above n 13 at [18]-[23].

190 Ibid, at [26].

191 Ibid, at [28].

192 Ibid.

193 Ibid, at [39].

194 Ibid, at [40].

195 Ibid.

196 Ibid, at [42]. Tierschutzgesetz roughly translates as "animal welfare or protection laws".

197 Ibid, at [44].

198 Ibid, at [51]. 


\section{FURTHER POLICY CONSIDERATIONS FOR THE FACILITATION OF RITUAL SLAUGHTER}

\section{A Animals as Property, Social Norms, and a Threshold of Tolerance}

Many arguments against slaughter focus on the animals' experiences. ${ }^{199}$ This reflects an increasingly popular notion that animals are not mere property, as at common law, which recognises two categories of animal: animals that are dangerous or wild by nature (ferae naturae, such as park animals) are not property, but become so if taken, tamed, or killed (in contrast to mansuetae naturae, such as farm and companion animals). ${ }^{200}$ While common law does not prevent slaughter, ${ }^{201}$ certain acts of cruelty are prohibited through legislation. ${ }^{202}$ Additionally, the circumstances where killing is permissible can be limited, such as by licence, ${ }^{203}$ or to holders of native title. ${ }^{204}$ The 'new' conception of animals takes these protections a step further, giving animals a more generous legal status, even positive rights (for example, to humane treatment in slaughter).

For the moment, animals only possess "negative rights", to which the proprietary conception is central. This remains desirable. Numerous activities of public benefit cause some degree of suffering, which would violate positive rights. They include dairy farming, egg production (for food and vaccines), use of laboratory rats, horse racing, pet breeding, and even public zoos. Indeed, the legality of all animal slaughter would be questionable. ${ }^{205}$ This undermines the "threshold of tolerance" that Western societies have long shown towards animal suffering, tolerated where it is not excessively or inherently cruel. Recreational hunting, for example, is a tolerated activity, ${ }^{206}$ although the question of a cut-off point remains controversial, as shown by the 2004 outcry following the Blair Government's ban on hunting dogs - "the ancient liberty of the British

199 See Factory Farming: Cruelty to Animals PETA.org (2010) People for the Ethical Treatment of Animals <www.peta.org>.

200 Yanner v Eaton (No 1) (1999) 201 CLR 351 at 387 per Gummow J.

201 Caulfield, above n 104, at [5.1].

202 Prevention of Cruelty to Animals Act 1979 (NSW); Prevention of Cruelty to Animals Act 1986 (Vic); Animal Welfare Act 1993 (Tas); Animal Welfare Act 2002 (WA); Animal Welfare Act 1992 (ACT); Animal Welfare Act (NT); Animal Welfare Act 1985 (SA); Animal Care and Protection Act 2001 (Qld); Animal Welfare Act 1999 (NZ); note also the Convention on the Conservation of Migratory Species of Wild Animals, (opened for signature 23 June 1979, entered into force 1 November 1983) [1991] ATS 32.

203 Yanner v Eaton (No 1), above n 200, at 379-380 and 387-388 per Gummow J.

204 Native Title Act 1993 (Cth), ss 211 and 223.

205 Not necessarily the same as granting animals a "right to life", discussed in Poulter, above n 153, at 143.

206 See Wildlife (Game) Regulations 2001 (Vic); National Parks and Wildlife (Hunting) Regulations 1996 (SA); Wildlife Regulations 1995 (NZ); see also Hunting Act 2004 (UK), c 37; Alaska Department of Fish and Game Alaska Hunting Regulations and Game Management Units (2010) <wildlife.alaska.gov>. 
people". ${ }^{207}$ By the same token, it seems that suffering which fulfils a 'constructive' purpose is more likely to be tolerated (for example food or disease prevention).

Maintaining the current threshold of tolerance is more desirable than an animal rights model, though consistent application is a necessity. For example, it would be inconsistent to disallow ritual slaughter as 'inhumane', while allowing forms of commercial slaughter with comparable welfare risks. The fact meat is a staple of Western diets is also relevant; Schächten dismissed suggestions that the capacity of Sunni Muslims to adopt a Pescetarian diet satisfied religious freedom, as that would not reflect German eating habits. ${ }^{208}$ Meat plays a similar role in the Australian cultural landscape ${ }^{209}$ the exclusion of alternate notions of humaneness from the threshold excluding religious groups from the Australian national diet.

\section{B Intra-Religious Pluralism and Minorities within Minorities: When Mere Availability is No Availability at All}

Few religions are homogenous. Judaism, like Islam and Christianity, comprises numerous denominations and communities. If religions represent a smorgasbord of tradition and practices, an individual's denomination indicates what customs they might follow. Judaism has long experienced communal mitosis, new groups regularly formed due to theological disagreement, and from geographic heritage. ${ }^{210}$ For example, when Hassidic Judaism emerged in the 18th century, the Mitnagdim movement emerged to oppose it. ${ }^{211}$ As an extreme, members of "Jews for Jesus" identify as Jewish, despite their clear acceptance of Christianity. ${ }^{212}$ Similarly, being 'Indigenous Australian' does not indicate one's cultural and spiritual heritage. ${ }^{213}$ These minorities-withinminorities must be recognised where States explicitly regulate religious practice, dodging any fallacy of homogeneity.

207 R (Jackson) v Attorney General [2005] UKHL 56, [2006] 1 AC 262 at 293 per Steyn LJ; see, "Pro-hunt protesters storm Commons" BBC News (15 September 2004) <news.bbc.co.uk>; "Mass hunt protests to mark ban" BBC News (10 December 2004) <news.bbc.co.uk>

208 Schächten, above n 13, at [11] and [40].

209 Linda Tapsell "Meat in the context of the whole diet: A social and cuisine perspective" (2007) 64 Nutrition \& Dietetics 108 at 110 .

210 For a very basic overview see Robert Fawcett "Jewish Denominations" (2010) The Major Religions of the World <www.majorreligionsoftheworld.com>.

211 See Joseph Telushkin Jewish Literacy: The Most Important Things to Know About the Jewish Religion, Its People and Its History (William Morrow, New York, 1991) at 224.

212 Jews for Jesus Australia "What We Believe" (2008) <www.jewsforjesus.org.au>.

213 Victorian Equal Opportunity and Human Rights Commission Indigenous Australians and Diversity (2006) <www.humanrightscommission.vic.gov.au>. 
Recall the only Jewish body licensed to perform Shechita in France was the Orthodox Jewish ACIP, prompting an ultra-Orthodox group to litigate. Perhaps the most problematic aspect of the majority view was their conception of French Jewry, a minority group itself, as a single group. No consideration was given to the applicant and ACIP being separate liturgical associations under French law. The majority felt the applicant's Shechita-methodology was largely the same as the ACIP, and considering their being less representative of French Jewry, ${ }^{214}$ despite the applicant's concerns. Because one Jewish sect undertook Shechita, the majority, in effect, felt no other sect needed to. The proposition is that States, rather than groups themselves, can determine if meat is fit for communal consumption, or, in the majority's words, if it is impossible for groups to acquire meat that the state considers acceptable. This is bad law. Indeed, the authority of the ruling was undermined by the listing of three alternatives to allowing Shechita. I would question why, if the ACIP was competent to perform Shechita for all French Jews, was it necessary to even discuss alternatives? Though intended to bolster the majority position, these alternatives detract from it.

Communal autonomy aside, the narrow approach is impractical in Australia or New Zealand. No foreign kosher meat is available in Australia, with all goods produced by local establishments. In New Zealand, the 2010 changes to the Commercial Slaughter Code meant the only meat available was Australian red meat. By contrast, poultry became entirely unobtainable, local production being illegal and imports restricted. This was excessive, and would have raised significant issues for the New Zealand High Court.

But Cha'are Shalom also highlights the dangers of granting the right to manifest to one segment of a larger group, no matter how representative. ${ }^{215}$ Whether or not they are actually different, each community's Shechita involves perceived differences, based upon the individuals involved, their involvement giving confidence in the meat's integrity. This explains why, in Melbourne today, communal Kashrut Authorities (Adass Israel and Chabad, Mizrachi) arrange kosher certification. Until the late 1990s, many businesses held generic certification from the former Melbourne Beth Din (run by affiliates of the United Hebrew Congregations of the Commonwealth), ${ }^{216}$ which disappeared as more consumers demanded boutique kashrut. ${ }^{217}$ The issue is recognition: do consumers recognise the authority of a group to provide kosher certification? Without recognition, otherwise kosher products are considered unfit for consumption, even if Jewish law is followed to

214 Cha'are Shalom Ve Tsedek v France, above n 12, at [77]-[81].

215 See Poulter, above n 153, at 93-95.

216 As distinct from the current Melbourne Beth Din, established in 2004. The former Beth Din was dissolved in 2002 after the retirement of Rabbi Sholem Gutnick.

217 Kluwgant, above n 15, at [31]. 
the letter. As such, where a state does not permit a Jewish community to perform Shechita because another communal group performs it, they are left without meat. ${ }^{218}$

\section{Separation of Church and State: Respecting Religious Autonomy, and Acknowledging the Dangers of State "Neutrality"}

An increasing number of individuals argue that international law represents a "transformative framework" for religion, as Charlesworth labelled it regarding women's rights. ${ }^{219}$ The proposition goes that some religious values must fall outside the international freedom, as they undermine another value expressed in the source instruments (for example democracy, rights). The ECHR took this view in Refah Partisi (Welfare Party) $v$ Turkey, ${ }^{220}$ ruling Sharia law was incompatible with the principles of democracy and human rights in the European Convention. ${ }^{221}$ The case appealed the Turkish Constitutional Court's dissolution of the Welfare Party, whose activities - specifically, the goal of introducing some Islamic law into Turkey's secular political system - were deemed contrary to the Turkish Republic's secular character. ${ }^{222}$ This approach continued in Sahin v Turkey, ${ }^{223}$ where the ECHR ruled that, while a prohibition against students wearing headscarves or having beards during class and assessment at Istanbul University did restrict religious freedom, the European Convention will permit restrictions that facilitate reconciliation of various group interests, and "ensure that everyone's beliefs are respected". ${ }^{224}$ Critics argue this neutrality approach oppresses those the European Convention seeks to protect, embracing a values judgement regarding the acceptable scope of religious liberties. ${ }^{225}$

The relevance of this approach for Shechita is that other important values, other than social and political liberties, such as animal welfare, might conceivably receive treatment. Even where the practical implications are desirable (for example restricting Islamic fundamentalism), it undermines

218 Ibid, at [32].

219 Hilary Charlesworth "The Challenges of Human Rights Law for Religious Traditions" in Mark W Janis and Carolyn Evans (eds) Religion and International Law (Martinus Nijhoff Publishers Kluwer Law International, The Hague, 1999) 401 at 411.

220 Refah Partisi (The Welfare Party) v Turkey (2003) 14 BHRC 1 (ECHR).

221 Ibid, at [120]-[125].

222 Ibid, at [12] and [23]-[26].

223 Leyla Şahin v Turkey (2005) 19 BHRC 590 (ECHR).

224 Ibid, at majority judgment [106].

225 Malcolm Evans and Peter Petkoff "A Separation of Convenience? The Concept of Neutrality in the Jurisprudence of the European Court of Human Rights" (2008) 36 Religion, State and Society 205 at 208209; Malcolm Evans "Human Rights and the Freedom of Religion" in Michael Ipgrave Justice and Rights: Christian and Muslim Perspectives (Georgetown University Press, Washington DC, 2009) 109 at 115. 
the substratum of the freedom of religion. It would be a huge mistake for this attitude to enter the international law vernacular on a greater scale.

\section{THE FUTURE OF SHECHITA IN AUSTRALASIA: PROPOSALS FOR GREATER TRANSPARENCY}

Though present arrangements in Australia and New Zealand satisfy the nations' international obligations, neither represents a perfect regulatory approach, one that best balances the interests of religion and animal welfare. Two possible paths for reform are:

(1) To restrict ritual slaughter to smaller animals; or

(2) Better regulation.

The first, proposed by Adams and Sheridan (on the proviso of further research), ${ }^{226}$ raises problems on merits and under the international freedom. While limitations based upon size and time to unconsciousness seems sensible, I question its necessity. As discussed, poultry and sheep, which are not stunned, remain conscious for only a short period after sticking, there being welfare benefits in the lower throughput of poultry production. By contrast, while the risks for cattle are greater, those are dealt with effectively through post-stunning.

This restriction also raises questions of necessity and proportionality under the international freedom. As discussed, slaughter is not a pleasant experience for the animals. In welfare terms, ritual slaughter only differs from ordinary methods at the end of the farm-to-abattoir cycle. There being a social threshold of tolerance for animal suffering, even if ritually-slaughtered animals experience marginally greater pain than those pre-stunned, overemphasis on the differences only at this stage is hypocritical, given the multitude of causes for distress earlier on. It would also exclude alternative perspectives on kindness to animals.

This brings us to better regulation, improvements upon the existing, self-regulated system. Recall that all Shochetim in Australia are employed by kashrut authorities, and outsourced to meat processors under those authorities' supervision. All Shochetim undergo rigorous training, being subject to post-qualification assessment by their rabbinic authority. While this system works well, it lacks transparency, ${ }^{227}$ though that reflects the entire system of training and qualification for Australian slaughtermen (determined privately under quality assurance programmes). ${ }^{228}$ By

226 Adams and Sheridan, above n 8, at 71.

227 Barnett, Cronin and Scott, above n 10, at 48.

228 Meat processing facilities must provide for staff training as part of their quality assurance arrangements, as indicated in Quality Management Systems - Requirements (AS/NZ ISO 9001). This has been implemented on both sides of the Tasman: see Meat Industry Act 1993 (Vic), s 11(h); Animal Welfare (Commercial Slaughter) Code of Welfare 2010 (NZ), s 36 [Minimum Standard 24]; see generally Caulfield, above n 104, at [5.2]. 
contrast, slaughtermen in the United Kingdom can only practice after obtaining a certificate of competence from an authorised veterinarian. ${ }^{229}$

It should be borne in mind that Australia has only 12 regular Shochetim (excluding the Israeli Shochetim employed by the export processor), ${ }^{230}$ plus a number of practicing apprentices. This reflects that kosher production is a boutique market. As such, while establishing a United Kingdomstyle rabbinic licensing commission might best enhance transparency, the costs involved make that option inefficient. A more viable option is requiring that all Shochetim be assessed by an approved veterinarian (though if only ritual slaughtermen require assessment, discrimination is an issue).

The best way to enhance transparency, without interfering in the Shechita process, would be the direct regulation of Shochetim. This would not involve any change to the existing, dispensationbased mechanism under the Australian Meat and Poultry Standards (though drafting a model quality assurance programme for facilities undertaking ritual slaughter might result in perceptions of greater transparency). However, only licensed ritual slaughtermen would be allowed to play an active role (for example perform the incision). The conditions of such a licence might include:

(1) Obtaining a veterinary certificate of approval;

(2) That ritual slaughter may only occur under the auspices of, or in conjunction with, a registered religious authority (for example kashrut authority), though deciding an authority's eligibility for registration may be contentious; and

(3) Creating registers of ritual slaughtermen, including a Register of Shochetim. Only individuals on the register would be entitled to practice (excepting apprentices). This would ensure the satisfaction of certain formalities before a Shoichet begins practice, such as vetinary approval, and verification of their acceptance to shecht by local rabbinic authorities. ${ }^{231}$ For practical reasons, room should be made for provisional licensing.

Through these formal hurdles, the state can be confident that all Shochetim satisfy some local standards. The primary benefits would be where local kashrut authorities decide to hire Shochetim from overseas, or where local operations seek to hire the Shochetim from overseas authorities. Such measures, being tailored to the local industry, would satisfy the concerns of all stakeholders in Australian Shechita.

229 The Welfare of Animals (Slaughter or Killing) Regulations 1995 (UK), sch 1, s 4.

230 Kluwgant, above n 15, at [34].

231 Given this information is of a private nature, and the contentious nature of ritual slaughter, the Register would have to be exempted from freedom of information requirements. 


\section{PRACTICES OTHER THAN SLAUGHTER}

\section{A Mandatory Labelling?}

I discussed earlier how the international freedom might tolerate labelling of ritually-slaughtered meat might qualify for on the basis of fundamental rights and freedoms (consumer knowledge). However, if we accept that the welfare risks are manageable, there are questions as to the informative value of labelling, and as such, what sort of labelling is necessary and proportionate. Form, in this respect, is quite relevant. Large or visually-unappealing labels, similar to the graphic warnings on Australian cigarette packets, for instance, would be problematic, the deterrent effect being far greater than information provided. But that said, appropriate presentation alone (for example, alongside nutritional information) may be insufficient.

There is a discrimination argument that, if kosher and Halal meat is labelled "slaughteredwithout-stunning", all meat should display its method of slaughter (for example electrocution, shooting, gassing, clubbing). ${ }^{232}$ If labelling is about consumers' rights to information, surely the state must provide all relevant information. Indeed, if kosher and Halal meat are singled out, it might simply promote social stigma, and allow consumers to act upon their misconceptions. Considering also that kosher meat is produced in relatively small amounts (Australia processes 7 million non-kosher chickens weekly compared to 16,000 kosher chickens), ${ }^{233}$ the merits of labelling are questionable, the cost likely to be disproportionate.

There is also the practical impact of labelling. It would have little impact on the primary kosher industry, whose products identify them as such. ${ }^{234}$ But there is also a secondary industry, nonkosher processors to whom those parts which cannot be processed kosher are sold, usually below market rates. This includes off-cuts (for example, the hindquarter being up to 70 per cent of the animal), ${ }^{235}$ rejects (for example, those that fail kosher standards), and excess (in other words, too much product). ${ }^{236}$ Labelling would give this market three options: label all products as "may contain ritually-slaughtered meat" (which could deter uninformed consumers), segregate such meat and distinctively package it, or stop purchasing it altogether. Given the relatively small amounts purchased, the perceived costs of kosher-specific labelling, social and monetary, would certainly

232 "European Parliament proposal would identify kosher slaughter" Jewish Telegraphic Agency (New York, 17 June 2010) <jta.org/news>.

233 Barnett, Cronin and Scott, above n 10.

234 The word "kosher" and a kashrut authority badge of certification will be present, for instance, on packing, or on the signage of a business.

235 "European Parliament proposal would identify kosher slaughter", above n 232.

236 For an outline of this distinct market, see Interview with Victor Smorgon (Robin Hughes, Television Interview for Australian Biography, 25 March 1998) <www.australianbiography.gov.au>. 
negate the incentive to purchase. That would severely harm the primary industry, whose costs would skyrocket if unable to offload this large quantity of meat.

\section{B Processed and Live Exports: Availability versus Overseas Participation}

An area the international freedom has not been explored in is processed exports, specifically, whether States would violate the international freedom by implementing policies to prevent kosher or Halal processors from exporting abroad. From a risk management perspective, this should not be a problem if proper procedures exist to cope with the greater welfare risks in the larger-scale processes. New Zealand continues to oppose the establishment of a kosher export trade, which the government justifies by arguing - given their position that Shechita is inhumane - that the New Zealand meat export trade would be jeopardised if the country were not viewed as a world leader in animal welfare. ${ }^{237}$ Were that argument raised in Australia, I would draw attention to the greater regional Jewish community's reliance on Australia for kosher meat. This not only includes New Zealand, but many smaller Jewish communities throughout the Asia-Pacific for whom local Shechita is unviable. The international freedom applies beyond the citizenship of the State, and in my view, States which adopt policies that prevent the export of ritually-slaughtered meat to paying, overseas markets must necessarily be found to be in breach of their international obligations.

This obligation to provide meat may be narrower when it comes to live animal exports, a controversial topic in Australia since the airing on the ABC's Four Corners "A Bloody Business" (which exposed the poor treatment of Australian cattle in Indonesian abattoirs). ${ }^{238}$ Australia exports a sizeable amount of livestock to Muslim customer nations - in particular, sheep to the Middle East, and cattle to Indonesia ${ }^{239}$ - and those animals are slaughtered using Halal methods. That the animals are intended for ritual slaughter is not an issue. What is an issue is overseas welfare standards. Though it can seek undertakings, Australia cannot guarantee its trading partners will apply the same welfare standards as would Australian abattoirs, and in these circumstances, the international freedom may be limited by morals, specifically, the encouragement of good welfare risk management beyond Australian borders. Indeed, as an extreme, States might make supply conditional upon its customers adopting that State's own welfare policies. If, consequently, affected religious groups cannot obtain acceptable meat produced within their own borders that would be immaterial. If meat produced in the supplier state were not satisfactory to the customer group (for example, a different form of Halal), the restriction on exports would not prevent those customers

237 See National Animal Welfare Advisory Committee (New Zealand), above n 82, at 23-24.

238 Sarah Ferguson Australian Broadcasting Corporation "A Bloody Business" Four Corners (30 May 2011) <www.abc.net.au>

239 "Australia and New Zealand" in Michael Appleby and others (eds) Long Distance Transport and Welfare of Farm Animals (Companion Animal Behaviour Institute, Wallingford, 2008) 324 at 325-336. 
making arrangements to conduct ritual slaughter overseas, the customer's own personnel (religious staff) being sent to supplier States for that purpose. While these options may be costlier, the obligation only requires that the availability of meat be facilitated, making no demands upon the particular form of such a scheme.

There are instances, however, where States must recognise the greater significance of participating in ritual slaughter. In Islam, the festival occurring immediately after the Hajj is Eid AlAdha (the Festival of Sacrifice). This necessitates a Muslim to personally slaughter an animal, with the intention of making a sacrifice, or Udhiya. ${ }^{240}$ From a welfare position, the participation of untrained laypersons in ritual slaughter may be problematic if proper precautions are not taken (for example, proper supervision and administration of a post-stun). Similar issues arise in Kaparot (atonement), a Jewish ritual performed in the lead-up to Yom Kippur (the Day of Atonement). ${ }^{241}$ Participants hold a chicken above their head, and circle it three times while reciting a prayer. This symbolically transfers their sins to the bird, which is slaughtered in substitution by a Shoichet, and donated to a charity. The participation of laypersons here, as in Udhiya, is problematic, many participants showing extremely bad technique (for example poorly grasping the bird, "swinging" rather than gently circling) and many Jews instead use currency (also given to charity). Where live exports allow group participation in these "quasi-ritual slaughter" customs, the considerations of necessity and proportionality must differ from ordinary considerations brought up for live exports. $^{242}$

\section{CONCLUSION}

The legality of ritual slaughter remains contentious. It is characterised by unpleas ant and heated discussions on how the relevant scientific literature is to be interpreted, with constant accusations from welfare activists that religious groups are more interested in antiquated practice than needs of animals. In this article, I have sought to objectify the debate, both on merits and regarding the international freedom of religion.

Meat consumption is commonplace in the West, including Australia and New Zealand. The dietary regulations of both Judaism and Islam continue to be central to these religions. States must show respect for that centrality, by recognising that - despite their different perspectives to the state on kindness to animals - both aim for slaughter which entails minimal pain. That some aspects are incompatible with secular conceptions of humanity is insufficient to exclude these groups from

240 Hüseyin Algül The Blessed Days and Nights of the Islamic Year (The Light, Izmir, 2005) at 71.

241 See generally The Complete Artscroll Machzor (Ashkenaz): Yom Kippur יום כפור (16th ed, Menorah Publications, New York, 2000) at 2-4; Richard Schwartz "The Custom of Kaparot in the Jewish Tradition" (2010) Jewish Virtual Library <www.jewishvirtuallibrary.org>.

242 I am unable to confirm whether Australian live exports are intended for any such quasi-ritual slaughter custom. 
having an Australia Day barbeque. Even if there were absolute scientific evidence showing that ritual methods caused measurably more pain to animals, Western values continue to tolerate a degree of animals' suffering, so long as it is not excessive or inherently cruel, which neither religion is.

The international freedom of religion requires that States allow religious groups to obtain meat which is acceptable to their beliefs. This necessitates that States establish procedures to facilitate local slaughter, where those groups deem there to be no alternatives. Indeed, if groups overseas perform ritual slaughter according to local welfare standards, States have no moral reason to oppose live animal exports. As Cha'are Shalom shows, where States decide on those groups' behalf whether these alternatives satisfy their beliefs, the mere availability of these alternatives can result in no availability at all. The minority judgment in Cha'are Shalom, and the Schächten judgment, recognise that it is for the group and its members to decide what meat satisfies their religious requirements.

The New Zealand Government's effective ban on Shechita was a concerning development for the international freedom. New Zealand continues to base its animal welfare policies upon subjective values judgements, rather than an objective approach, such as risk management. The absolute nature of the ban - which did not acknowledge the impact that physiological differences in poultry, sheep and cattle may have on welfare risks - affirmed the caprice of the policy. It was implemented despite ordinary slaughter also causing pain, thereby undermining any grounds under which New Zealand could argue for an exemption to the international freedom of religion.

In writing this article, I hope to enhance the quality of public debate on ritual slaughter. Given its small scale in Australia and New Zealand, the concerns of the kosher meat industry are vulnerable to being drowned out by the sheer determination of animal welfarists as they seek to further their otherwise admirable mission. The international freedom demands that religious groups have access to meat produced in accordance with their beliefs, and while the state does have a role to play, its role should be one of facilitation and oversight, not intervention. These traditions are more than the strong feelings of relatively small religious minorities. 